\title{
Approaches to Decision Making in Foreign Policy: Literature Review
}

\author{
Kristine Zaidi \\ Department of Political Science, University of Latvia, Riga, Latvia \\ Email address: \\ krimiz@me.com
}

\section{To cite this article:}

Kristine Zaidi. Approaches to Decision Making in Foreign Policy: Literature Review. Journal of Political Science and International Relations. Vol. 4, No. 2, 2021, pp. 48-55. doi: 10.11648/j.jpsir.20210402.14

Received: May 3, 2021; Accepted: May 17, 2021; Published: May 26, 2021

\begin{abstract}
There is a substantive amount of literature on decision-making in public policy. Most of this is on decisionmaking in domestic settings and less so on decision-making in foreign policy. As the field continues to evolve, offering more disciplinary perspectives, from political science to neuroscience, there is increasing scholarly interest in how the science of decision has moved forward. Understanding the process of decision-making has pre-occupied thinkers for centuries. The complexity of pluralistic societies, multiplied by the additional layer of international interactions, characterise the complexity, as too the gravity, of the tasks for contemporary analyst. Through this literature analysis, the author demonstrates that the general principles in decision-making are ubiquitous regardless of the decisions. The role and influence of structure and agency have varied over time and lead to diverse predictive outcomes, and equally, the varying reflective analyses. The paper demonstrates that while division lines on inputs from the different disciplines and bodies of literature are blurred, the science of decision hinges on universal factors. These include context, the relationship between agency and structure in the system paradigm, choices, behaviours, cognitive abilities and constraints of individual decision-makers, and the possession and development of the capability to deliver on policy.
\end{abstract}

Keywords: Decision-Making, Foreign Policy, Agency, Structure, Rational Actor

\section{Introduction}

The emergence of a decision, whether that is foreign policy, business or any other sphere of activity, implies the end of one process - that of arriving at that decision, and the beginning of another, typically, the strategy and planning necessary for deliberate action to advance policy. The process of coming to a decision has been a subject of intense debate in political, business and administrative sciences. The scientific approach to decision making has profound roots. The more well-known works include Sun Tzu's Art of War [1], which delves at estimates to influences such as Friar Luca Pacioli [2], a Franciscan monk, mathematician and associate of Leonardo da Vinci. Pacioli devised what he called the 'problem of points' to teach rational decision making. His model, following contributions by Cardano [3] and Tartaglia [4], among others, inspired Blaise Pascal and Pierre de Fermat [5], who attempted to take the gamble out of gambling in the game Balla ${ }^{1}$. Pascal devised a system to calculate every possible outcome during a game and scientifically work out how to distribute stakes to maximises chances of winning. The foundation of contemporary decision models in business and public policy have evolved from the classical period to the estimates process, combining analytical and mathematical modelling, as witnessed in the modern era. This synthesis of economic models and rational decision models was increasingly applied to foreign policy during the Cold War, where economic models [6] and analytical models [7] were further synthesised [8] to inform international relations and comparative politics. Today these models have further evolved and extend to the lower levels of political economy and public policy [9]. This paper looks at foreign policy decision-making and provides a focussed analysis of the literature and its contribution to contemporary approaches to decision-making in public policy.

\footnotetext{
${ }^{1}$ The game's origins date back to $5200 \mathrm{BC}$. It is popular in Italy as bocci and is similar to the British variant called bowls or bowling.
} 
The paper starts with a broad overview of the evolution of thinking on decision-making before narrowing it down to a particular focus on foreign policy. It aims to introduce a wide range of literature stemming from various disciplinary writings on the subject. It argues that the study of decisionmaking in politics is intrinsically inter-disciplinary, as demonstrated throughout this review. Decision-making is always contextual with all its complexities and uncertainties; above all, it is a people's process and is directly related to their position, abilities, interests, values and even emotions, and the capability to see through a decision.

In classical thought, the faculty and right to the decision were associated with personalities and most typically the heroic leader, as evidenced in the works of Aristotle and later Machiavelli. While this moderated to some extent in the classical Roman model where democracy, aristocracy and monarchy were fused [10], it was not until the 20th century that this paradigm shifted from individual agency towards a dominant role of formalised structures. This shift is most prominent in the emergence of international organisation and in the way western democracies operate. This evolution in domestic politics and international order occurred due to a series of epochal events, World War I, World War II and the Cold War [11]. Society, government, international norms, and the actions and behaviours of the major actors on the international stage were all impacted. In the western democracies, the overall impact was a diminishing or deemphasising of the role of agency. At the same time, within national socialism and communism, the old paradigm of agency or, at the very most, moderated agency resurfaced. More recently, with the resurgence of nationalistic politics, there is appears to be a transition or at the very least a concurrence of structure and agency as prime movers in the decision-making process [12].

\section{Agency and Process}

High stakes, ambiguity and uncertainty typically characterise foreign policy decisions, and therefore are not without substantial risk [13]. Decisions occur in an environment that Barber describes as volatile, uncertain, complex and ambiguous [14]. More often than not, the decisions themselves are complex and appear puzzling not only for the outsiders but also for insiders. The monopoly of government, or rather a small group within the government, in decision-making is also expressed in its highest degree (perhaps only comparable with defence policy). Renshon and Renshon take the argument on monopolisation further, emphasising the role of individual leaders, arguing that no crises or war can be understood "without direct reference to the decision-making of individual leaders" [15]. Lunenberg echoes this argument saying that while decision-making is an essential administrative process, it is fundamentally a people process [16]. The emphasis on agency is evident in relatively recent literature.

The history of decision sciences has been alluded to in the introduction. In this section, the author will look at the fluctuating balance between the role of agency and structure. From Aristotle deliberations on ethics of decision to the formal study of the subject in the formalised theories developed by Lindblom and Allison and Zelikow in the last century, the interest in the science of decision continues to the present day. The complexity of pluralistic societies, multiplied by the additional layer of international interactions, in a volatile and uncertain global environment characterise the complexity, as too the gravity, of the tasks for contemporary policymakers and analyst. The analyses that pre-dates the more distributed models of decision making, such as Hobbesian attributes to sovereignty, are arguably more straightforward. That said, they are also complex because they require an understanding of the context for each analysis. Hobbs talks about the diversity of opinion, both political and religious; however, he attributes the right to censor both to the sovereign. In doing so, he recognises sovereign rights to decide across the realms, including notions such as 'just' and 'unjust' [17]. On the other hand, Locke provides a different idea of sovereignty, putting sovereign power with the majority within civil society. Therefore, he proposes limiting the role of government as in classical liberalism and later in the public choice concept. All members of society, he argues, have equal right to participate in limited government and also possess negative freedom from excessive government ${ }^{2}$.

Hobbes' notion clashes sharply with Rousseau's ideas that a man (reflective of the time it as written) who had no part to play in the exercise of sovereignty of his country was no better than a slave [18]. Political leaders are there to be an agent of the people rather than independent decision-makers. This is arguably an aspirational model that suggests limited agency of decision-makers and ambiguity of structures. However, such notions played a key role in fuelling the idea of broader political participation and electoral representation underpinning the idea of direct democracy, its modern manifestation. The first balanced system of government first found its practical expression after establishing the constitutional monarchy in England. Occurring in the second part of the $17^{\text {th }}$ century, this post-revolution English government led to the dynamic and not challenge-free relationships between the sovereign and the Parliament i.e. executive and legislature. Edmund Burke, the conservative politician and political thinker, who opposed the revival of the King's influence in England, captures these ideas in his writings. These foundations eventually became constitutionalised in a more defined way, with checks and balances in the US. The notion of shared decisions is more apparent, and no one is supposed to have a monopoly. This emphasis on due process means that only when decisions went through an established process could they be considered legitimate. As such, a more significant role of structures emerges. Public acceptance of decisions made within these

\footnotetext{
${ }^{2}$ This corresponds with an old idea that the good life could not be lived unless political decision-making was widely shared. For example, Thucydides opposed excess and advocates moderation in statecraft, even during a war. Prudence is seen as a check on unrestrained ambition
} 
structures also became part of their legitimate status [19]. This explains why, for example, Tom Paine, the English political philosopher and outspoken republican, considered American and French constitutions legitimate; while Edmund Burke cast doubts about the legitimacy of the English/British constitution.

Reflecting on public role in governance and decisionmaking, Max Weber noted that an ideal participatory democracy is impractical in large and complex modern societies. He proposed that governance must instead be in the hands of an elite administration that cannot be directly accountable to the masses. A contrary arrangement would make for inefficiency and unpredictability, especially since Weber views the general public as irrational and ignorant. Democracy, therefore, is less a rule of the people but rather the rule of an elite, which combines exceptional leaders and bureaucratic experts [20]. While Weber emphasises the role of elites, their agency is moderated by structures. Weber takes a pessimistic view that most of the population is uninterested in and ignorant of political matters. This elitecentric approach contradicts the view taken by Immanuel Kant and later elaborated upon by John Rawls, who emphasises the role of individuals, seen as rational and reasonable, and the concept of equal representation (Rawls' first principles) manifested via the vote [21]. Also, Weber's approach most certainly goes at odds with Marx's ideal of egalitarian society as a rational rule. Sociological studies that reflect on the impact of elites on decision-making could provide further insights for those interested in the Weberian view on governance [22].

Robert Dahl took a much more inclusive view, noting that everyone is involved somehow in the political system [23]. He considers direct or indirect participation in decisionmaking. For Dahl, this brings in responsibility, not only for political leaders but also for ordinary citizens. For the former, it would entail developing some capacity in political analysis and an increase in analytical competencies to respond adequately to increasing complexities of international and domestic politics. For the former, it would entail developing a more in-depth appreciation of the political process to make a judgement about political leaders and their policies, the way the alternatives are considered and decisions made. It would be a departure for both groups, moving beyond their direct experience and what they learn from it [24]. While suggesting broader participation and representation, Dahl's approach defuses the notion of agency as the number of actors increases across the range of structures. In this sense, Alison's proposition of limiting decisions to key players provides a more realistic approach to decision-making, particularly in foreign policy.

\section{The Intersections Between Foreign and Domestic Policy Decision Making}

Decisions in foreign policy occur in a complex environment well described by Barber. This section will look at the role of domestic political dynamics and stakes in foreign policy decision-making that forms an important part of the context that every analyst needs to consider when analysing decisions and actions of actors on the international stage. Kissinger used to express the complaint that it was easier to negotiate with the Soviet leaders than negotiate on agreed-upon policy in Washington. Even between long standing collaborators, international negotiations can come to a standstill or break down because of domestic frictions within a government on either or both sides of the house of executives.

Robert Putnam offered an interdisciplinary perspective on the decision-making process, emphasising international negotiations, conceptualising and theorising empirical observations. Looking through the prism of comparative politics and international relations, he offered a structured view on relations between domestic and international politics that "are often somehow entangled" [25]. However, in what way, when and how, remains unresolved in any meaningful and structured way. Moving beyond a well-established perception that both influence each other sometimes in some way, Putnam attempted to shed some light on the complexity of these relationships, seeking theorisation that would establish a basis for future analysis.

Putnam's argues that the then-existing literature that attempted to clarify the link between foreign and domestic policymaking has not moved beyond the catalogued instances on such influence. However, it is worth adding that a body of literature looking at the intersections between domestic and foreign policy exists. For example, in the late 1970s, Snyder and Diesing noted that the prediction of international outcomes is significantly improved by understanding internal bargaining, especially with respect to minimally acceptable compromises [26]. The role of domestic factors in international politics were very well articulated by Halperin and Kanter. They noted that:

A focus on the international objectives of a state is essentially misleading, in the participants' attention primarily is focused on domestic objectives... The scholar requires an understanding of nation's domestic political structure and of its national security bureaucracy in order to explain or predict the foreign policy actions it will take. [27]

At the same time, Snyder and Diesing observed that at a practical level, "governments generally do not do well in analysing each other's internal politics [in crises], and indeed it is inherently difficult" [28]. And yet all agree that it is crucial.

Putnam rejected a state-centric approach to decision making grounding his view on the premise that decisionmakers [in pluralistic societies] are not a monolithic body. He argued that "it is wrong to assume that the executive is unified in its views" [29]. Central executive has a unique role in mediating domestic and international pressures precisely because they are directly exposed to both spheres, not because they are united on all issues nor because they are insulated from domestic politics.

Putnam described domestic-international interactions 
through a metaphoric comparison with a two-level game attempting to simultaneously reconcile domestic and international imperatives. The pressure of domestic groups at the national level that government attempts to maximise at international level while minimising the adverse consequences of foreign developments. Walton and McKersie, Daniel Druckman observe that a negotiator "attempts to build a package that will be acceptable both to the other side and to their bureaucracy [30]. The central decision-maker must be active at both levels of the game (negotiation and ratification) to successfully mitigate both to sustain inter-dependency with other countries and sovereignty. The strength of this model is that the domestic and international levels play the role of mutual enablers, aiming to achieve a 'general equilibrium' that accounts simultaneously for the interaction of domestic and international factors. It is, for example, manifested when national governments adopt policies that they would not have pursued in the absence of international engagements or negotiations due to political contestations at a national level.

Although elaborative, Putnam's analysis is limited to international negotiations. However, its contribution to knowledge is indisputable. In this regard, the works of other authors, albeit not explicitly grounded in decision making literature but rather in international political economies, such as in the analysis of Jeffry Freiden and Lisa Martin, could provide further insight that can also apply to the decision making process. Putnam's two-level game framework features in their analysis inadvertently related to decision making at both international and domestic levels and understanding of their interactions. A broader overview is one of the impacts of domestic institutions and interests on global interactions and vice versa [31]. Frieden and Martin join the argument that the integration of the domestic and international levels of analysis is a crucial next step.

\section{The Synthesis of Decision Thought and Behaviour}

In the context of the importance of developing various actors' understanding of decision-making, Isaiah Berlin offers a valuable and straightforward classification [32]. His analogy of thinkers and writers was later adopted for decision-making analysis. Berlin divided thinkers into two groups: 'foxes' (inductive pragmatists) or 'hedgehogs' (deductive generalists) [32]. The idea was later extended to forecasting and decision making in various fields (particularly politics) through the experimental work of Philip Tetlock [33]. These categorisations are useful in analysing leader behaviours. ${ }^{3}$ However, one needs to be

\footnotetext{
${ }^{3}$ Hedgehogs know one big thing profoundly and extend what they learn into other domains of policy analysis. They are poor at making long-term predictions; they are likely to drive policy in a consistent direction even when they are wrong. Foxes know 'many small things and are particularly strong at providing shortterm forecasts; they are more likely to drive policy in a more dynamic, adaptive direction. They are more open to new information.
}

mindful of its seeming simplicity and, as in many other things, the synergy of two paradigms that do not exclude interchangeable behaviour, providing a more insightful understanding.

Whether hedgehogs or foxes, the act of adopting a policy, particularly an important one, requires taking a decision or series of related choices. Political or policy decisions are nearly always surrounded by a cloud of uncertainty; the Clausewitzian analogy of the fog of war [34] is relevant here. In this fog, foxes would be better equipped to respond, considering the flexibility of their approach to decisionmaking, both in terms of matters of fact and matters of value, Kantian deontology balanced by Bentham's utilitarianism [35]. The ability to employ strategies that may help to improve the quality of decisions amid the uncertainties by choosing the best available alternatives becomes very important. Dahl's commentary on the strategy of enquiry is also beneficial when studying the decision-making process. For example, as an attempt to understand causes to obtain desired results, causal analysis is crucial to analysing decision making. Add to that judgements about the value, moral quality, or goodness of different prevalent, powerful, and complex alternatives in politics. Here it is worth returning to Kant, who in his famous political guidelines for the statesman, said that policy should be established on the principles of morality [36]. In other words, the relative importance of a matter of 'fact' as we see it depends on our standard of value [37] and the standard of value, beliefs, and convictions of the subject of analysis. The idea is central to studying decision-making as it helps to develop a more comprehensive understanding and, at the same time, reduces the risk of biases that will be discussed later in this review.

Without a direct reference to a rational actor model, Dahl argues that in the circumstances of uncertainties associated with decision making, those who study, try to adopt to limited knowledge and apply strategies of 'perfect rationality' - sometimes called synoptic or holistic approaches - that attempt to search for a rational answer before a choice is made. This strategy appeals only in abstract, considering it unattainable in practice [38]. Moreover, he concedes to critics who say that making the model of "perfect rationality is useless and may even be harmful [39]. Dahl's commentary suggests that his preference lies with the incremental approach to decision-making due to its balances and responsiveness to uncertainties. It is often the only one available for making decisions.

\section{Decision Making as People's Process}

If public policy is 'what government ought or ought not to do, and does or does not do' [40], decision making is inherently part of the second premise around actions and inactions. Understanding why and how decisions are made (or not made) is not as straightforward as one may assume. Nuances, such as the balance between interest and values, are important, combined with time and resources (broadly understood) - these are just a few notions thrown into the 
mix. In foreign policy, political decisions are typically characterised by high stakes, enormous uncertainty, and substantial risk [41]. Renshon and Renshon put a specific emphasis on the role of Individual leaders, arguing that no crises or war can be understood 'without direct reference to the decision making of individual leaders' [42]. Lunenberg echoes this argument saying that while decision-making is an essential administrative process, it is fundamentally a people process. [16]

The decisions themselves are more often than not complex and appear puzzling, not only for the outsiders but also for insiders. Because of the nature of foreign policy, the monopoly of government, or rather a small group within the government, in decision-making is expressed in its highest degree (perhaps only comparable with defence policy). Here, it is the government actions (or inactions) that one needs to untie to be able to understand what (action) is happening and why in the foreign policy of a particular country within a given period (context). The correlation between action and context and vice versa can give a comprehensive analytical framework in a pathway to shed some light and untangle at least part of the stretches in the mysterious decision-making process, where values of decision-makers play an important role for an analyst to take into account. Thomas Shelling brings in the Kantian aspect of value system that guides the calculations crucial in decision making: 'the assumption of rational behaviour - not just of intelligent behaviour, but of behaviour motivated by a conscious calculation of advantages, a calculation that in turn is based on an explicit and internally consistent value system'. [43]

Reflecting upon earlier studies on decision making in foreign policy, including that of Allison and Zelikow [44, 45], John Spanier summarised that the decision-making approach to understanding the foreign policy of a country is based on the assumption that one should look at individuals responsible for making foreign policy and the positions they occupy. ${ }^{4}$ Among primary things, this analysis needs to include the perceptions of decision-makers and their vision of the world [46]. This approach is equally relevant to understanding the domestic decision. The role of perceptions and misperceptions in decision-making is instrumental. As Jervis argues, a common misperception is to see the actions of others as more centralised, planned, and coordinated than they are, and there may be a tendency to squeeze complex and unrelated events into a coherent pattern [47]. It is echoed in Herbert Simon's analysis of 'bounded rationality. Simon argued that rationality is bounded by human nature, the boundaries of which are impossible to predict a-priori [48]. It moves away from the notion of comprehensive rationality,

\footnotetext{
${ }^{4}$ Alison and Zelikow argued that most analysis explains (and predicts) the behaviour of national governments and international relations in terms of one basic conceptual model, often referred to as the Rational Actor Model. While this model has its advantages, it only offers a limited framework for analysis due to its simplification and broad assumption that there is a notion of pre-set goal multiplied by the value-maximising behaviour in attempt to achieve it and discounts branches and sequels that are inescapable in a complex, dynamic and adaptive system.
}

recognising the unavoidable limitations of knowledge and human ability, acknowledging and accepting the values, beliefs, and stereotypes of the decision maker, regardless of what these constraining influences are [49]. This position is echoed in Lindblom and Braybrooke's writing on the incremental decision-making model [50] that considers the disparity between the requirements of rationality and the capacities of decision-makers [6]. Due to the complexity of most problems decision-makers have to face when it comes to international relations, they are not amenable to total rationality, and decision-makers 'must start from the existing policy and take, remedial steps to cope with problems as they arise [51]. As Spanier put it, policymakers do not go through the rational procedure each time they have to make a decision. They neither have time nor resources to do that. Instead, they pick the policy that is likely to be most satisfactory, and inform their choice based on the level of success in the past [52].

In the work of political psychologist Robert Jervis, this argument is taken further. ${ }^{5}$ Jervis argues that agents have limits to their cognitive capacities [40, 52, 53]. Thus understanding agency is imperative for analysis of decisionmaking in organisations [54]. Beach concludes that decisionmaking models that depart from the rational actor model are better equipped to capture the agency involved in decisionmaking process. It is not enough to know what the goals and objectives of an individual are, it is important to understand their beliefs, norms, values and behaviours as well as their ability to draw inferences from the information they possess. Jervis argued that once a leader believes in something, that perception would influence the way they perceive all other relevant information [51]. Therefore, it could also impact their approach to the selection of information they deem to be relevant to support their formed perceptions. However, as Jervis concludes, this may also lead to common errors. As Simon argues, decisions are made on satisfactory rather than optimal information [51]. Optimal may not only relate to the quantity but, more importantly, to the quality of information and the way it is selected and used to support perceptionbased decision making. In this discussion, it is also important to note that actors' perceptions and beliefs about international relations and other actors are not constant and are indeed a subject of change [55] and should be examined over a longer period able to draw any meaningful conclusions.

Shelsle and Bonchek discussed the concept of instrumental rationality that implies acting in accord with one's preferences and one's beliefs. A rational individual combines their beliefs about the external environment and preferences about things in that environment in a consistent manner. Authors go into great detail explaining the logic of preference and choice but conclude in simple terms that individuals are characterised in a very abbreviated form,

\footnotetext{
${ }^{5}$ Derek Beach [54] also devotes a lot of discussion to cognitive aspects of decision making. He refers to the conceptual model of Snyder et al. [27] that focuses on individual decision-maker and how they define the choice they face. They also acknowledge the importance of external and domestic context within which decision are made.
} 
namely in terms of their preferences and beliefs. [56]

Cognitive psychology tells us that human beings have a preference for simplicity; they prefer consistency; they misunderstand the essence of probability and hence are poor estimators; they have risk profiles and hence are more averse to lose. Altogether, Stein argues, these factors "compromise the capacity for rational choice and affect the decisionmaking abilities of leaders who are responsible for foreign policy" [57]. Cognitive biases can lead to profound errors in attribution, which can confound policymaking. People exaggerate the likelihood that the actions of others are the result of their prior behaviour and, conversely, overestimate the extent to which they are the target of those actions - the 'egocentric bias'. In terms of analysis of others' behaviour, the fundamental attribution error can also provide further insight. This bias occurs when people exaggerate the dispositional importance over the situational factors explaining the disliked behaviour as a result of their disposition while explaining their own behaviour based on the situational constraints they face [58]. We tend to rationalise the behaviour of others. At the same time, as Jervis' widely applied cognitive dissonance tells us that actors aim for consistency between attitudes and behaviours (and hence adjust one or another to maintain the balance) and, importantly, may not use very rational methods to achieve it [59].

Although still far from definitive, advances in neuroscience tell us that many decisions seem not to result from deliberative thought process but preconscious neurological processes. Also, many decisions seem to be the product of strong emotional responses. Moreover, emotion plays a dominant role in shaping behaviour as it is automatic and fast [60]. Indeed, several neurological studies confirmed that during the decision-making process, the zones of the brain governing the emotions are activated before cognitive reasoning has been consciously formulated [61]. The above suggests that studying emotions should provide a helpful insight into decision-making through developing a better understanding of decision-makers and personal factors that drive their choices.

\section{Conclusion}

There is a substantive amount of literature on decisionmaking in public policy. Most of this is on decision-making in domestic settings and less so on decision-making in foreign policy. This paper looked at the evolving field of decision sciences from a multi-disciplinary perspective and how diverse fields, such as political science, psychology and management studies, contribute. While the science of decision continues to move forward, the complexity of foreign policy decision-making and the volatility of the environment within which policy decisions are made continue raising a substantial interest in academic circles that attempt to explain the matter through research. The author provides a broad overview of decision making thought, highlighting contributions that authors from various disciplinary backgrounds made over the years. The review exposed that the division between domestic and international decisions is neither possible nor desirable, particularly when it comes to international relations. Siloed domestic and international decision-making is not possible in the increasingly interconnected world that requires 'intramestic' decisions.

The interdisciplinary nature of studying decision-making is evident. The way we approach decision making finds its roots in political philosophy; its most known contemporary models have been developed by economists and advanced by sociologists and psychologists. It derives the insights from a broad base of social sciences and often broadens its outreach to the disciplines outside the social sciences. Division lines are blurred, and hence, while reflecting on inputs from the literature of major sub-disciplines, this review has not been structured around the disciplines as such but rather around the issues associated with the art and science of decisionmaking.

This article shows the science of decision hinges upon context (volatile and complex), the relationship between agency and structure in the system paradigm, cognitive abilities and constraints of individual decision-makers, and notably the possession and development of the capability to deliver on policy. While existing literature provides solid foundations for developing a broad understanding of each of these components, it is a systemic view on the relationship and interdependencies between agency, structure, capability and context that requires further investigation.

\section{References}

[1] Sun Tzu (2013) The Art of War, Lionel Giles (tr.) Abingdon, Oxon: Routledge.

[2] Luca Pacioli is considered the father of modern-day accounting. He introduced the concept of double-entry bookkeeping. See Murphy Smith (2018) "Luca Pacioli: The Father of Accounting". Rochester, NY. doi: 10. 2139/ssrn.2320658. S2CID 170867923. SSRN 2320658. This statistical problem has its roots in Arabia and first appears in Italian texts in 1380 and was passed on to Pascal in 1654. For Luca Pacioli's other contribution, see. John J O'Connor and Edmund F Robertson (2018) A Napierian logarithm before Napier, Online https://mathshistory.standrews.ac.uk/Extras/Pacioli_logarithm.

[3] Girolamo Cardano, (1968) The Great Art or the Rules of Algebra, T. Richard Witmer (tr.), MIT Press. Originally published in 1545 under the title Ars Magna (also, Artis Magnae, Sive de Regulis Algebraicis Liber Unus). For early thinkers and their contributions to mathematics, see Ronald Calinger, (1999), A contextual history of Mathematics, Prentice-Hall.

[4] Mac Tutor, (n.d.) 'Nicolo Tartaglia' https://mathshistory.standrews.ac.uk/Biographies/Tartaglia/ Accessed 15 March 2021. Nicolo Tartaglia's 1536 work on arithmetic was an influence on Gerolamo Caradano and was only published in Cardano's Ars Magna [3]. 
[5] F. N. David (1962) Games, Gods, and Gambling, Griffin Press, p. 239. Blaise Pascal and Pierre de Fermat 1654 work led to the development pf their Probability Theory, an essential component in decision and Game Theory.

[6] Charles Lindblom, "The Science of Muddling Through", Public Administration Review, 19 (2), (1959); David Braybrooke and Charles E. Linbdom (1963) A Strategy of Decision. New York: Free Press; Charles E. Lindblom (1965) The Intelligence of Democracy. New York: Free Press.

[7] Graham Alison and Philip Zelikow (1999) Essence of Decision. Explaining the Cuban Missile Crises ( $2^{\text {nd }}$ edn). New York: Longman.

[8] Amitai Etzioni (1967) "Mixed Scanning: Third Approach to Decision Making", Public Administration Review, Vol. 27, No. 5.

[9] Peter John (2017) "Theories of the policy change and variation reconsidered: a prospectus for the political economy of public policy". Policy Sci, 51, 1-16 (2018). https://doi.org/10.1007/s11077-017-9297-x.

[10] Z. S. Brown (2016) "How Democratic Was The Roman Republic? The Theory and Practice of an Archetypal Democracy". Inquiries Journal [Online], 8. Available: $\mathrm{http} / / / \mathrm{www}$.inquiriesjournal.com/a?id=1492.

[11] Philip Bobbitt (2002). The Shield of Achilles: War, Peace, and the Course of History. New York: Alfred A. Knopf. ISBN 0375-41292-1.

[12] John Peterson (2018) "Structure, agency and transatlantic relations in the Trump era". Journal of European Integration, 40: 5, 637-652, DOI: 10.1080/07036337.2018.1489801.

[13] Jonathan Renshon and Stanley A. Renshon (2008) "The Theory and Practice of Foreign Policy Decision-Making". Political Psychology, Volume 29, Issue 4 (2008), p. 509.

[14] Herbert F. Barber (1992) "Developing Strategic Leadership: The US Army War College Experience", Journal of Management Development, 11 (6), pp. 4-12. See also Harry R. Yarger (2006) Strategic Theory for the 21st Century. Virginia: National Defence University Press.

[15] Jonathan Renshon and Stanley A. Renshon, "The Theory and Practice of Foreign Policy Decision-Making". Political Psychology, Volume 29, Issue 4 (2008), p. 511.

[16] Fred C. Lunenberg, (2010) "The Decision-Making Process". National Forum of Educational Administration and Supervision Journal, Volume 27, 4. pp. 1-12.

[17] J. S. McClelland (1996) A History of Western Political Thought. London: Routledge, pp. 204-208. On sovereign and its critique, see C. B. Macpherson (1962) The Political Theory of Possessive Individualism. Hobbes to Locke. Oxford: Oxford University Press, pp. 90-95.

[18] Christian Simon, Public Policy: Preferences and Outcomes, Routledge: Abingdon, New York, 2016, pp. 3-4.

[19] J. S. McClelland (1996) A History of Western Political Thought. London: Routledge pp. 370-371, 394-5.

[20] Kate Nash (2000) Contemporary Political Sociology. Globalisation. Politics and Power. Blackwell Publishers Inc., p. 12.

[21] Christian Simon (2016) Public Policy: Preferences and
Outcomes. Abingdon: Routledge, p. 9.

[22] For example, Süleymanoğlu-Kürüm provides a helpful literature review on the subject matter. See Rahime Süleymanoğlu-Kürüm (2020) "The Sociology of Diplomats and Foreign Policy Sector: The Role of Cliques on the PolicyMaking Process", Political Studies Review, 1-16, DOI: 10.177/147892920901954.

[23] Robert A. Dahl (1984) Modern Political Analysis (4th edn). New Jersey: Prentice-Hall. pp. 1-4.

[24] On citizens' political behaviour, see Edward G. Carmines and Robert Huckfeldt (1998) "Political Behavior: and Overview", in A New Handbook of Political Science, Robert E. Goodin and Hans-Dieter Klingemann (eds.), Oxford University Press, pp. 223-254. Carmines and Huckfeldt discuss a model of a citizen as a cost-conscious consumer and the process of political information. They, while taking duties seriously, reduced the impulse to be consumed by politics and political affairs.

[25] Robert D. Putnam (1988) "Diplomacy and domestic politics: the logic of two-level games", International Organisations, 42 : 3 , pp. 427-460, this p. 427.

[26] Glenn H. Snyder and Paul Diesing (1977) Conflict Among Nations: Bargaining, Decision Making, and System Structure in International Crises. Princeton: Princeton University Press, pp. 510-25.

[27] Morton H. Halperin and Arnold Kanter (1973) Readings in American Foreign Policy: A Bureaucratic Perspective. Little Brown \& Co. p. 3.

[28] Glenn H. Snyder and Paul Diesing (1977) Conflict Among Nations: Bargaining, Decision Making, and System Structure in International Crises. Princeton: Princeton University Press pp. 516, 522-23.

[29] Robert D. Putnam (1988) "Diplomacy and domestic politics: the logic of two-level games", International Organisations, 42: 3 , pp. $427-460$, this p. 432 .

[30] Daniel Druckman (1978) "Boundary Role Conflict: Negotiation as Dual Responsiveness," in I. William Zartman, ed., The Negotiation Process: Theories and Applications. Beverly Hills: Sage, pp. 100-101, this p. 109. For a review of the social-psychological literature on bargainers as representatives, see Dean G. Pruitt (1981) Negotiation Behavior. New York: Academic Press, pp. 42-43.

[31] For example, see Jeffry Friend and Lisa L. Martin (2002) "International Political Economy: Global and Domestic Interactions, in Katznelson, I. and Milner, H. V. (eds.) Political Science. State of the Discipline. New York: W. W. Norton and Company, pp. 118-146.

[32] Isaiah Berlin (1953) The Hedgehog and the Fox: An Essay on Tolstoy's View of History. London: Weidenfield and Nicolson.

[33] Philip E. Tetlock (2005) Expert Political Judgment: How Good Is It? How Can We Know? Princeton: Princeton University Press.

[34] Carl Von Clausewitz (1979) On War, Michael Howard and Peter Paret (tr.), London: Princeton.

[35] Robert A. Dahl (1984) Modern Political Analysis (4th edn). New Jersey: Prentice-Hall. p. 138. 
[36] Hadley Arkes; James Child; Charles W. Kegley and Terry Nardin (1977) "Perspectives on Values, Ethics, and National Security", in Richard H. Shultz, Jr., Roy Godson and George H. Quester (eds) Security Studies for the 21st Century. London: Brassey's Inc. This contradicts George Kennan and other postWWII thinkers' beliefs that bringing morality in international politics can be dangerous and wrong. Nations are in a 'state of nature' toward each other; hence no morality or justice is required. See also Mary Maxwell (1990) Morality Among Nations, Albany: State University of New York Press.

[37] Robert A. Dahl (1984) Modern Political Analysis (4th edn). New Jersey: Prentice-Hall. pp. 138-142.

[38] See also Derek Beach (2012) Analysing Foreign Policy. Palgrave McMillan.

[39] Robert A. Dahl (1984) Modern Political Analysis (4th edn). New Jersey: Prentice-Hall. p. 143.

[40] Christian Simon (2016) Public Policy: Preferences and Outcomes. Abingdon: Routledge, pp. 1-2.

[41] Jonathan Renshon and Stanley A. Renshon (2008) "The Theory and Practice of Foreign Policy Decision Making". Political Psychology, 29, 4. pp. 509-536, this p. 509. On uncertainty and complexity of decision-making see also Robert Huckfeldt (1998) "Political Behavior: and Overview", in A New Handbook of Political Science, Robert E. Goodin and Hans-Dieter Klingemann (eds.), Oxford University Press, pp. 223-254, this pp. 245-248.

[42] Jonathan Renshon and Stanley A. Renshon (2008) "The Theory and Practice of Foreign Policy Decision Making". Political Psychology, 29, 4. pp. 509-536, this p. 511.

[43] Thomas Schelling (1960) The Strategy of Conflict. Cambridge: Harvard University Press, p 4.

[44] Janice Gross Stein (2009) "Foreign policy decision making" in S. Smith, A. Hadfield, A. Dunne A (eds.). Foreign: Theories, Actors, Cases. Oxford: Oxford University Press.

[45] For further critique of the model see for example, Alexander Grashow, Ronald Heifitz and Marty Lynsky (2009) The Practice of Adaptive Leadership, Boston: Harvard Business Press; Jonathan Bendor and Thomas H. Hammond (1992) "Rethinking Allison's Models" in American Political Science Review, 86, 2; see also [7, 9].

[46] John Spanier, (1984) Games Nations Paly: Analysing International Politics $\left(5^{\text {th }}\right.$ edn,). Holt, Rinehart and Winston. p. 409.

[47] Robert Jervis (1976) Perceptions and Misperception in International Politics. Princeton: Princeton University Press p. 319. On perception, see also [55] pp. 111-115.

[48] Herbert Simon (1985) 'Human Nature in Politics: The
Dialogue of Psychology with Political Science', American Political Science Review 79 294-304. Also Herbert Simon (1982) Models of Bounded Rationality. Cambridge: MIT Press.

[49] Jarvis devoted a lot of attention to the role of perceptions in international relations. On values in public policy see Christian Simon (2016) Public Policy: Preferences and Outcomes. Abingdon: Routledge, pp. 37-50.

[50] For a critique of Lindblom's Incremental model, see, for example, Y. Dror (1964) "Muddling Through - "science" or inertia?", Public Administration Review, 24 (3); Amitai Etzioni (1968) The Active Society: A Theory of Societal and Political Processes. New York: Free Press; and Christian Simon (2016) Public Policy: Preferences and Outcomes. Abingdon: Routledge.

[51] Robert Jervis (1976) Perceptions and Misperception in International Politics. Princeton: Princeton University Pres, p. 77.

[52] John Spanier, (1984) Games Nations Paly: Analysing International Politics (5th edn,). Holt, Rinehart and Winston. pp. 419-420.

[53] Richard Snyder, Henry W. Bruck, Burtin Sapin (1954) Decision-Making as an Approach to the Study of International Politics. Princeton: Princeton University Press.

[54] Derek Beach (2012) Analysing Foreign Policy. Palgrave McMillan. p. 99.

[55] Shafritz, Layne and Botick (2005) Classics in Public Policy, New York: Longman, pp. 23-24.

[56] Kenneth A. Shepsle and Mark S. Bonchek (1997) Analysing Politics. Rationality, Behaviour, and Institutions. New York: W. W. Norton \& Company. pp. 15-36.

[57] Janice Gross Stein, (2016) "Foreign policy decision making" in Foreign Policy: Theories, Actors, Cases ( ${ }^{\text {rd }}$ edn). S. Smith, A. Hadfield, A. Dunne (eds.), Oxford University Press. pp. 130-146, this p. 133.

[58] Susan T. Fiske and Shelley, E. Taylor (1984) Social Cognition: From brains to culture. Sage Publishing. pp. 7299.

[59] S. A. McLeod (2014) Cognitive dissonance. Retrieved from https://www.simplypsychology.org/cognitive-dissonance.html, accessed on 6 January 2018.

[60] Janice Gross Stein, "Foreign policy decision making" in Foreign Policy: Theories, Actors, Cases, S. Smith, A. Hadfield, A. Dunne (eds.), Oxford University Press, p. 140.

[61] Jean-Frederic Morin and Jonathan Paquin (2018) Foreign Policy Analysis. A Toolbox. Palgrave Macmillan. pp. 71-72. 